University of Nebraska - Lincoln DigitalCommons@University of Nebraska - Lincoln

Papers in Natural Resources

Natural Resources, School of

2014

\title{
A Retrospective Examination of Paleoparasitology and its Establishment in the Journal of Parasitology
}

Charles T. Faulkner

Lincoln Memorial University, charles.faulkner@lmunet.edu

Karl Reinhard

University of Nebraska-Lincoln, kreinhard1@mac.com

Follow this and additional works at: http://digitalcommons.unl.edu/natrespapers

Part of the Life Sciences Commons, and the Social and Behavioral Sciences Commons

Faulkner, Charles T. and Reinhard, Karl, "A Retrospective Examination of Paleoparasitology and its Establishment in the Journal of Parasitology" (2014). Papers in Natural Resources. 402.

http://digitalcommons.unl.edu/natrespapers/402

This Article is brought to you for free and open access by the Natural Resources, School of at DigitalCommons@University of Nebraska - Lincoln. It has been accepted for inclusion in Papers in Natural Resources by an authorized administrator of DigitalCommons@University of Nebraska - Lincoln. 


\title{
A RETROSPECTIVE EXAMINATION OF PALEOPARASITOLOGY AND ITS ESTABLISHMENT IN THE JOURNAL OF PARASITOLOGY
}

\author{
Charles T. Faulkner and Karl J. Reinhard* \\ College of Veterinary Medicine, Lincoln Memorial University, Harrogate, Tennessee 37752. Correspondence should be sent to: charles.faulkner@lmunet. \\ edu
}

\begin{abstract}
Volume 95 (2009) of the Journal of Parasitology represented a significant benchmark in the history of paleoparasitology when it received on the cover formal recognition as a topical area for publication. This retrospective examination chronicles the emergence of paleoparasitology, from its origins as an adjunct contribution to the study of prehistoric human populations to its modern expression as a sub-disciplinary interest. The aim of paleoparasitology is to elucidate the temporal and spatial dimensions of parasitism from the fossil record of human and non-human host populations.
\end{abstract}

Paleoparasitology is the study of parasitism in animal and human host populations of the past. Deriving its theoretical foundation and analytical methods from the discipline of parasitology, Professor Luiz Fernando Ferreira, a Brazilian parasitologist from the Oswaldo Cruz Institute, is generally credited with defining the sub-discipline and its scope of study. The scientific contributions in paleoparasitology, refinement of its analytical technologies, and evolution in the nature and complexity of the research questions currently being addressed by its practitioners have been the subject of several excellent reviews (Dittmar, 2009; Araújo et al., 2013; Dutour, 2013; Reinhard et al., 2013). In keeping with the theme of our Centennial Volume, the intent of this essay is to provide a chronologic perspective on the origins, development, and establishment of paleoparasitology as a sub-discipline within in our broader field of scientific inquiry.

Ruffer's (1910) description of calcified Schistosoma hematobium eggs in the kidney tissues of 2 Egyptian mummies is the historically acknowledged origin of paleoparasitology research. The current record of scientific contributions in the study of paleoparasitology spans 7 decades since Professor Szidat published the first note on the occurrence of Ascaris lumbricoides, Trichuris trichiura, and Diphyllobothrium latum eggs in the intestinal contents of 2, 5th Century corpses interned in an East Prussian bog (Szidat, 1944). Taylor (1955) demonstrated the potential usefulness of diagnostic methods developed in veterinary parasitology in the recovery of helminth eggs from Roman age sediments in England. Parasitism in the prehistoric inhabitants of the New World was first described by Tulio Pizzi, Professor of General Pathology at the Universidad de Chile (Pizzi and Schenone, 1954). Eggs of T. trichiura were observed in the intestinal contents of an Incan mummy along with possible cysts of Entamoeba coli. These studies are noteworthy for the early interest in the antiquity of parasitic infections in human populations. However, it can be argued that the publication of Volume 95 of the Journal of Parasitology in 2009 was an equally significant benchmark in the history of paleoparasitology when it received formal recognition as a topical area for publication. From that point on the study of parasitism, and its preservation in the fossil record of animal and human hosts, would have a discrete forum for exchange of ideas, methodologies, applications for its data, and peer review by experts within the international community of parasitologists.

DOI: $10.1645 / 13-485.1$
This essay on the history of paleoparasitology is developed from a review of the literature since the 1960 publication of Professor T. W. M. Cameron's (Cameron, 1960) description of Diphyllobothrium sp. eggs from desiccated feces attributed to the prehistoric inhabitants of Huaca Prieta on the Peruvian coast (Callen and Cameron, 1960). For the period between 1960 and 2014, approximately 665 publications, inclusive of book chapters, technical reports, and journal articles, were identified with Google Scholar using the search term "paleoparasitology" included anywhere in the text or title. Additionally, scientific papers published in peer-reviewed journals addressing topics in paleoparasitology were identified through PubMed using the following key term: paleoparasit*OR archaeoparasit*; parasit* AND archaeo*; parasit* AND paleo*. Papers were identified for each decade to describe some of the events, issues, and people that have played a significant role in history and development of paleoparasitology.

\section{DISCOVERY AND DESCRIPTION: 1960s AND 1970s}

With the exception of Taylor's (1955) study of archeological sediments associated with a human settlement, the evidence for parasitic infection in prehistoric humans was based largely on the examination of mummified remains. However, it is generally acknowledged that the aforementioned paper by Callen and Cameron (1960) was the first to demonstrate the potential wealth of data regarding human health and diet contained in coprolites, or desiccated feces, recovered from archaeological and paleontological deposits. The significance of the paper resonated throughout the scientific community. It was especially well received among anthropologists and archaeologists seeking to understand the interactive relationship between culture, diet, and health of prehistoric populations. Although the largest portion of the paper was devoted to a discussion of the dietary contents, it was Professor Cameron's contribution in the last paragraphs that were to be instrumental in defining the scope of paleoparasitology during the following decades. He specifically commented on the potential of these data for understanding the pre-Columbian origin of parasitic infections in Native Americans. In doing so, he established the relevance of subsequent studies that would attempt to address issues of theoretical interest in the broader field of parasitology.

In 1961, a short note published in the obscure Bulletin of the Israel Exploration Society provided another example of parasitism in prehistoric humans based on the analysis of desiccated fecal material (Wittenberg, 1961). The identification of E. coli, 
Entamobea histolytica, Giardia lamblia, and Chilomastix mesnili heightened the awareness of future researchers that the delicate cysts of these protozoan species could be preserved in ancient fecal material. Robert Samuels, a parasitologist at Meharry Medical College, known more for his work with Tritrichomonas sp. (e.g., Samuels, 1957), published an extensive parasitological analysis of feces recovered during excavation of the cliff dwellings at the Wetherhill Mesa, better known as Mesa Verde National Park (Samuels, 1965). Eggs of Enterobius vermicularis, in addition to free-living rhabditoid nematodes and mites associated with stored grains, were noted among the approximately 800-yr-old samples. An interesting note in this paper is that he was unaware of the Callen and Cameron (1960) study published 5 yr earlier, as indicated by the description of his rehydration procedure based on sodium hydroxide and EDTA. Two papers published in 1966 and 1967, respectively, documented the occurrence of $A$. lumbricoides, T. trichiura, and Dicrocoelium dendriticum in sediments associated with an 11th Century latrine in England (Pike and Biddle, 1996; Pike, 1967). Significantly, the authors stressed that one of the most critical issues confronting scientists in this area of research is determining human origin for the samples analyzed. The other 3 papers of this period also documented parasitological findings from prehistoric feces preserved in cave deposits in the arid desert region of the southwestern United States. Two of the papers were deemed significant enough that they were published in Science (Fry and Moore, 1969; Moore et al., 1969). Acanthocephalan eggs, found in feces approximately 4,000-yr-old, were presumably from Moniliformis clarki (Moore et al., 1969). The authors noted that human infections were facilitated by consumption of orthopteran intermediate hosts and specifically referenced the ethnographic study of such dietary behavior among the historically known Native American residents of the region (Steward, 1933). The pinworm eggs reported in the subsequent study were found in a 10,000-yr-old fecal sample and considered to be the oldest known occurrence of the parasite in humans (Fry and Moore, 1969). Digenean trematode eggs resembling species in the family heterophyid or opisthorchiid were reported in a third paper from the American Journal of Physical Anthropology (Moore et al., 1974). The occurrence of these eggs was considered evidence of "false" parasitism based on the inability to identify precisely the egg and the details of the parasite's life cycle. The unique preservation environment afforded by the aridity of this geographic region would yield many more specimens in the succeeding decades that increasingly enriched our understanding of the cultural ecology of parasitism in the prehistoric human population. It is of interest that only 4 of the 8 papers published during that decade were based on analyses conducted by scientists with training in parasitology, i.e., Cameron, Samuels, and Pike, and none of the papers was published in journals specific to the study of parasitism.

Papers published in the 1970s documented the occurrence of $A$. lumbricoides and $T$. trichiura in feces associated with prehistoric salt mining activity in Austria (Aspock et al., 1973). Cockburn and colleagues reported on the autopsy of an Egyptian mummy in which a single egg of $A$. lumbricoides was observed (Cockburn et al., 1975). A short descriptive note, by the distinguished veterinary parasitologist Peter Nansen, reported recovery of parasite eggs in sediments associated with a Viking-age settlement in Ribe, Denmark (Nansen and Jorgensen, 1977). This was the first such study conducted in Denmark and further established the association of $T$. trichiura and $A$. lumbricoides eggs with human residential sites. Additionally, the eggs of Fasicola sp. and Taenia sp. were observed in the prehistoric fossil record for the first time (Nansen and Jorgensen, 1977).

It can be argued that the most significant paper of this period was the report of pre-Columbian hookworm infection in a Peruvian mummy (Allison et al., 1974). The parasite was identified based on the histologic cross-section of an adult worm and showed the mucosal tissues of the small intestine drawn into the buccal capsule (Allison et al., 1974). This discovery fully substantiated the pre-Columbian origin for hookworm infection in Native American populations first postulated by Darling (1920) and Soper (1927). This finding and other documented occurrences in the next decade would stimulate significant discussion on the trans-pacific migration of humans and their parasites that would not be fully resolved until the 21st Century (Ferreira and Araújo, 1996; Hawdon and Johnston, 1996; Pigg, 2001; Faulkner and Patton, 2001; Reinhard et al., 2001).

\section{THE FORMATIVE YEARS: 1980s AND 1990s}

The 1980s and 90s are recognized as a formative period in the development of paleoparasitology. The increased number of studies conducted worldwide distinguishes this era. The term paleoparasitology made its first appearance in the title of publications. Papers published during this period were largely descriptive in nature, providing additional examples of parasitic infection in new temporal and spatial contexts. Studies from China (Wei et al., 1981; Hu, 1984; Yang et al., 1984), France (Bouchet, 1995, 1997), the United Kingdom (Jones and Nicholson, 1988), North America (Reinhard et al., 1987; Faulkner et al., 1989), South America (Ferreira et al., 1980; Araújo et al., 1981; Ferreira et al., 1983; Kliks, 1983; Horne and Kawasaki, 1984; Araújo et al., 1985), Greenland (Sadler, 1990), and the Aleutian Islands (Bouchet et al., 1999) fully established the cosmopolitan distribution of parasitism in ancient human populations.

Forty-seven papers featuring research in paleoparasitology were published in 25 different journals. Over $50 \%$ of all research findings during this period were published in the Journal of Parasitology (15\%), Memórias do Instituto Oswaldo Cruz (13\%), and the non-peer-reviewed forum Paleopathology Newsletter $(23 \%)$. Contributions from the laboratory of Professor Luiz Ferreira and colleagues at the Oswaldo Cruz Institute in Brazil accounted for a significant portion $(23 \%)$ of the submissions. Noteworthy among these discoveries were the findings of hookworm eggs and larvae in 4,000-yr-old fecal samples (Ferreira et al., 1980) and the recovery of hookworm-like eggs from the colon of a mummy (Ferreira et al., 1983). These 2 studies demonstrated that the earlier description by Allison et al. (1974) was not an isolated finding and appeared to close the book on the pre-Colombian antiquity of hookworms in the New World. However, a contentious review of the evidence by Fuller (1997) would keep the issue in the forefront of the debate on hookworm antiquity into the 21 st Century.

Reinhard et al. (1987) and Faulkner et al. (1989) were the first paleoparasitology papers published in the Journal of Parasitology. Reinhard et al. (1987) provided a regional overview of parasitic findings for the Colorado Plateau. This was the first effort to draw 
on the accumulated archaeological data from multiple locations and time periods in the same geographic region and describe the diachronic changes in patterns of parasitism as a function of culturally expressed subsistence and residential behaviors. The unique preservation environment of the arid southwestern United States, and its extensive archaeological record, would yield additional data in the subsequent decades for development of a paleoepidemiologic picture of host-parasite interactions involving humans and their companion animals. The paper by Faulkner et al. (1989) was essentially a descriptive analysis of 8 desiccated feces from a prehistorically utilized cave in the southeastern United States. The study provided documentation for the preColumbian occurrence of hookworm in North America. However, another noteworthy contribution of the research was the first application of an immunofluorescent assay to stain and confirm the occurrence of Giardia sp. cysts in prehistoric feces (Faulkner et al., 1989). Subsequent efforts would demonstrate the applicability of immunodiagnostic methods for the detection of protozoan infections in prehistoric fecal samples (Allison et al., 1999; Gonçalves et al., 2002; Ortega and Bonavia, 2003).

With few exceptions, the diagnostic products of most of the parasitic species currently known from prehistoric context had been found on at least 1 occasion prior to 1980 . The accumulating database of parasitic findings recovered from archaeological sites gave rise to the initial efforts to review and synthesize these data with an eye toward elucidating the evolutionary biology of human-helminth parasite relationships as seen through the past (Kliks, 1983; Horne, 1985; Reinhard, 1990). Community hygiene and its role in the health of human populations from the prehistoric and historic era was emphasized from several studies based on the recovery of helminth eggs in mummified human remains from bogs and latrine sediments from archeological sites (Reinhard et al., 1986; Fries et al., 1990; Faulkner, 1991; Samford, 1991; Aspock et al., 1995; Aspock, 1996; Horne and Tuck, 1996).

In South America, parasitologists analyzed the first nonhuman feces from paleontological sites (Ferreira et al., 1991). They found Trichuris sp. eggs associated with feces of a small rodent, Kerodon rupestris, living in Brazil during the late Pleistocene period nearly 30,000-yr-ago. The parasite is not present in modern host populations and may be an example of an extinct host-parasite association (Ferreira et al., 1991). Subsequently, Ferreira et al. (1992) also found Eimeira sp. oocysts in 9,000-yr-old deer coprolites, representing the first coccidians known from the paleontological record. Schmidt et al. (1992) analyzed fecal samples from the extinct Shasta ground sloth, Nothrotheriops shastensis. The samples were radiocarbon dated to approximately 10,500-yr-ago, at the time of the host extinction. This study is noteworthy because the authors recovered juvenile nematodes suitable for detailed taxonomic treatment following the International Code of Zoological Nomenclature. Three parasite species, 2 nematodes, and 1 coccidian were described. To our knowledge, this was the first occasion that a new parasite species was taxonomically defined based on their occurrence in the fossil record. Jouy-Avantin et al. (1999) extended the antiquity of paleoparasitism into the Middle Pleistocene, nearly 550,000 yr before the present era, with the identification of apparent dicrocoeliid eggs from coprolites attributed to an extinct cave bear or hyena denning in the cave. Bouchet and Bentrad (1997) found eggs of the equine parasite Oxyuris equi associated with barrels that had been used as a cesspit for animal excrement. Prior to these efforts, paleoparasitology was largely anthropocentric and generally seen as an adjunct to archaeological research. These studies and others in subsequent decades would allow for the complete defining of paleoparasitology as the study of the temporal and spatial dimensions of parasitism in all host species.

While many of the studies during this period were diagnostic and descriptive, efforts to emphasize the interaction between parasite transmission and host behaviors were beginning to emerge as an interpretive paradigm. The global collaboration of scientists engaging in paleoparasitological research was facilitated by opportunities to participate in international conferences and increased communication through the Internet. These interactions led to efforts to standardize analytic methodologies (Reinhard et al., 1986; Araújo et al., 1998) and further collaborations between laboratories and researchers in the United States, South America, and Europe.

\section{THE SUB-DISCIPLINE OF PALEOPARASITOLOGY: 2000 TO THE PRESENT}

It can be argued that paleoparasitology achieved sub-disciplinary status in the larger context of parasitology in the $21 \mathrm{st}$ Century; this is a period in which molecular tools for diagnosis saw their first application. Moreover, the accumulating data of previous decades and contemporary studies were applied to a diverse range of topics in epidemiology, phylogeny, human migrations, and zoonotic transmission (Araújo et al., 2003, 2013; Dittmar et al., 2012; Leles et al., 2012; Reinhard et al., 2013). In this period, the number of self-identified researchers in paleoparasitology increased to more than 50 individuals worldwide. Researchers in Korea and Japan published their first work in the international forum outside of their countries (Han et al., 2003; Matsui et al., 2003). Approximately 574 articles, book chapters, and technical papers containing the key word "paleoparasitology" anywhere in the text or title were published since 2000. Publications during this period were dominated by no less than 24 synthetic reviews of the field of paleoparasitology, authored by its most prominent researchers. The cumulative findings in paleoparasitology were discussed by geographic region, taxonomic classification, and with respect to the application and innovation of diagnostic methodologies. Review articles also examined paleoparasitology for its importance to the evolution and development of human organization and migratory behaviors and chronicled the research efforts of previous decades and its implications for the future. The majority of peer-reviewed papers $(\mathrm{n}=108)$ were concentrated in the Journal of Parasitology and the Memórias do Instituto Oswaldo Cruz. Nearly $42 \%$ of these papers were published in the last $4 \mathrm{yr}$, reflecting the editors' commitment to provide a forum for the dissemination of research in paleoparasitology.

The first application of molecular diagnostic techniques in paleoparasitologic research occurred during this era. Loreille et al. (2001) extracted ancient DNA (aDNA) and amplified the gene sequence of $A$. lumbricoides from eggs preserved in coprolites recovered from a 14th Century latrine in Belgium. Subsequent papers documented the recovery of aDNA from eggs of $E$. vermicularis and $T$. trichiura preserved in coprolites and sediment samples (Iñiguez et al., 2003; Oh et al., 2010). The importance of these publications was implied by the application of molecular 
technology to a long-standing question of evolutionary interest in parasitology. Kliks (1983) was the first to suggest that the soiltransmitted nematodes $A$. lumbricoides and T. trichiura were originally parasites of swine that colonized humans with the advent of sedentary village life during the Neolithic period. Further study of the Ascaris sp. genome demonstrated that the answer to this question was neither simple nor straight-forward, and clearly required a multi-disciplinary approach by recognizing the contributions of paleoparasitology and biogeographic studies of modern populations (Loreille and Bouchet, 2003; Leles et al., 2012; Peng and Criscione, 2012).

Perhaps the real promise of the adoption of molecular diagnostic methods in paleoparasitology rests with the ability to identify occult parasitic infections in prehistoric host populations that are suspected, but otherwise undetectable. Rothammer et al. (1985) identified putative cases of Chagas' disease in 22 preColumbian-age mummies from Chile. The $54 \%$ prevalence was based on the occurrence of mega-colon and cardiomegaly at autopsy. However, the parasites were not visualized by microscopic examination of histologically stained tissues. The results were deemed reasonable based on the high rate of the disease in modern populations. In a molecular study of 283 separate mummies in South America, Aufderhide et al. (2004) isolated Trypanosoma cruzi aDNA from approximately $40 \%$ of the examined specimens. The prevalence of $T$. cruzi aDNA remained relatively constant over the 9,000-yr-period of study and suggested a relatively static pattern of disease transmission within the host population. Interestingly, the epidemiologic prevalence is comparable to modern populations in the region prior to the advent of recent control initiatives.

Recently published papers by Wood et al. (2013) and Cleeland et al. (2013) illustrated the complementary nature of combining molecular analysis of aDNA with the morphologic study of diagnostic parasite products in preserved fecal samples. Wood et al. (2013) examined feces of an extinct Moa (Aves: Dinorthiformes) from New Zealand. Six parasite taxa were identified based on analysis of aDNA and observation of helminth eggs. Parasite aDNA sequences of Cryptosporidium and Eimeriorina indicated the presence of infection in the absence of morphologic evidence. Cleeland et al. (2013) used aDNA sequencing in an effort to confirm the putative identification of ascarid eggs in a prehistoric canine fecal sample. The resulting analysis demonstrated that the eggs were likely Physaloptera sp., a spiruid nematode parasite that is relatively common, although difficult to diagnose, in canine hosts. Evidence of the parasite has rarely been found in prehistoric fecal samples (Fugassa et al., 2006). Myšková et al. (2014) likewise demonstrated the complementary use of microscopic and molecular methodologies in a study of 18th Century sediments from a well or cesspit in the Czech Republic. Their study represents the first occurrence of Encephalitozoon intestinalis aDNA in archeological material. Although the authors were unable to ascertain the human or non-human origin of the parasite, or its pathological significance, the investigation demonstrates the continuing promise of development and refinement of existing diagnostic technologies in parasitology and their application to the study of prehistoric and historic materials.

The aspirations of paleoparasitology researchers to contribute to the epidemiologic appreciation of parasite distributions in time and space have been fully realized in this period. By 2000, there was sufficient data collected regionally and globally to formulate hypotheses about the spread and distributional patterns observed in the recovery of helminth eggs from archaeological and paleontological sites. Fugassa et al. (2011) reviewed the extensive records of prehistoric infection with acanthocephalan parasite species from the Colorado Plateau and Great Basin regions of the southwestern United States. It is noteworthy that the occurrence of acanthocephalan eggs in prehistoric feces was once considered a spurious finding (Kliks, 1990) in isolated samples. However, following the examination of nearly 200 samples over a $50-\mathrm{yr}$ period, it was clear that this cumulative record was evidence of a significant epidemiologic pattern of infection derived from the systematic harvest and consumption of the orthopteran intermediate hosts. Convincing support for this interpretation was also based on ethnohistoric records (Steward, 1938) and dietary energetics studies demonstrating the subsistence behavior to be a significant evolutionary adaptation to the marginal environment in the desert southwestern United States (Madsen, 1989). Evidence of parasitic infection in the companion canines of prehistoric Native Americans, and its association with human activity and residential areas, suggested the possibility of zoonotic transmission between infected and susceptible host populations (Fugassa et al., 2011; Jimenez et al., 2012; Richardson et al., 2012).

Host migration and the spread of parasitic infections in human populations has been a topic of general scientific interest for decades (Darling, 1920; Soper, 1927; Manter, 1967). Demonstration of hookworms and hookworm-like eggs, as well as T. trichiura and A. lumbricoides eggs in fecal samples from archaeological sites that predated Columbian contact, fully substantiated earlier theoretical discussions regarding human migratory movement and the introduction of parasitic species in the Western Hemisphere. Three papers published since 2000 also focused attention on the translocation of parasitic species outside of their natural endemic areas. Mitchell et al. (2011) described the occurrence of $D$. latum from latrine sediments in the Medieval-period Kingdom of Jerusalem. The parasite was thought to have been translocated from its North European endemic area by soldiers and pilgrims traveling to the Levant during the 13th Century Crusades. Bouchet et al. (2002) documented the occurrence of Schistosoma mansoni eggs in the latrine sediments of a dwelling in Montbeliard, France dated to the 15 th and 16th centuries. Artifacts recovered from the household deposits indicated that the family was wealthy, and historical records provided support for the occurrence of African slaves in France by the middle of the 16th Century. As a parasite of African origin, it is likely that the eggs were introduced by an infected slave working in the household. Reinhard et al. (2008) described the occurrence of Clonorchis sinensis eggs in 19th Century latrine sediments associated with dwellings in the Chinese community of San Bernardino, California. These findings documented the past occurrence of an epidemiological process relevant to contemporary public health issues and globalization. Although neither of the parasites illustrated in these examples would have established life cycles for successful transmission, the analogous process of importing workers and their parasitic infections facilitated an outbreak of Taenia solium neurocysticercosis in the orthodox Jewish community in New York City (Schantz et al., 1992). 


\section{SUMMARY AND CONCLUSIONS}

The origins of paleoparasitology are found in the identification of $S$. hematobium in the tissues of an Egyptian mummy at the turn of the century (Ruffer, 1910). This was a classical period in the archaeological study of human civilization. Interest in the recovery of eggs from archaeological sediments and fecal samples occurred nearly 40 -yr later, with the expertise developing from the field of veterinary parasitology where such diagnoses are routine (Taylor, 1955). Paleoparasitology in its earliest application was pursued as an adjunct to archaeological studies of human settlements. Evidence of parasitic infection was valued for its ability to contribute to a conceptual picture of the health of prehistoric populations. In many respects, the diagnostic products of parasites found in archaeological sediments and fecal samples were another form of biofact (or ekofact), i.e., natural (biological) objects related to the environment in which humans interacted.

The demonstration of hookworm and whipworm eggs in prehistoric fecal samples from South American mummies was instrumental in the advancement of paleoparasitology and established its relevance for addressing questions of long-standing disciplinary interest (Manter, 1967; Allison et al., 1974; Ferreira et al., 1983). Scientific debate on the mechanisms and the migratory routes that facilitated the spread of the major helminth species infecting human populations in the Western Hemisphere would continue into the 21 st Century.

From the 1990s to the present time, paleoparasitology has benefited from the creativity and productivity of its researchers. The accumulated results from decades of analyses of thousands of samples provided a database for framing research questions addressing the transmission and distribution of parasites as a function of epidemiological and evolutionary processes. Increased communication through the Internet has facilitated greater opportunities for collaboration and standardization of methodologies among researchers world-wide. This, in turn, has stimulated greater interest in paleoparasitology, as reflected in the number of publications submitted to various journals by researchers and the establishment of laboratories and graduate training programs identified with the sub-discipline.

In contrast to its origins as an adjunct dimension in the study of prehistoric adaptive behavior and human health, the emergence of paleoparasitology as a distinct sub-discipline is broadly focused on elucidating the temporal and spatial dimensions of parasitism in host populations, both human and non-human. Papers by Bouchet et al. (2002), Reinhard et al. (2008), and Mitchell et al. (2011) reinforce the relevance of paleoparasitology to inform on timeless epidemiological processes such as the translocation of parasites to new environments and enhanced transmission opportunities for new host populations that arise from globalization. Studies on non-human fecal materials from paleontological sites in South America likewise helped to redefine the anthropocentric focus of paleoparasitology. These studies are important for their contribution in understanding the evolutionary processes affecting parasites and their host populations (Wood et al., 2013). The demonstration of extinct host-parasite relationships, such as that between the South American rodent, Kerodon rupestris, and its parasitic symbiont, Trichuris sp., (Ferreira et al., 1991) and the occurrence of oocysts resembling modern eimeriid species in extinct camelid hosts (Fugassa et al.,
2008), are important windows to the past for appreciation of evolutionary processes devoid of time and space connotations.

\section{ACKNOWLEDGMENTS}

We want to thank Jerry Esch for his support of paleoparasitology, inclusion of the research in the Journal of Parasitology, and the invitation to contribute to the Centennial Volume. Our ability to carry out the assigned duties and responsibilities of an Associate Editor is largely due to the tremendous effort and patience of Vickie Hennings. We are also appreciative of the efforts of our colleagues who graciously peer-review the manuscripts submitted for publication in the paleoparasitology section. These are the individuals responsible for maintaining the integrity and scientific value of the contributions to paleoparasitology. Finally, we want to acknowledge our colleague Dr. Vina Faulkner for her encouragement and support during the preparation of this paper.

\section{LITERATURE CITED}

Allison, M. J., T. Bergman, and E. Gerszten. 1999. Further studies on parasites in antiquity. American Journal of Clinical Pathology 112: 605-609.

, A. Pezzia, I. Hasegawa, and E. Gerszten. 1974. A case of hookworm infestation in a pre-Columbian American. American Journal of Physical Anthropology 41: 103-106.

Araújo, A., L. F. Ferreira, and U. Confalonieri. 1981. A contribution to the study of helminth findings in archaeological material in Brazil. Revista Brasileira de Biologia 41: 873-881.

$-\longrightarrow,-$ L. NuÑEZ, AND B. M. Ribeiro Filho. 1985. The finding of Enterobius vermicularis eggs in pre-Columbian human coprolites. Memórias do Instituto Oswaldo Cruz 80: 141-143.

- A. M. Jansen, F. Bouchet, K. Reinhard, and L. F. Ferreira. 2003. Parasitism, the diversity of life, and paleoparasitology. Memórias do Instituto Oswaldo Cruz 98: 5-11.

, K. Reinhard, O. M. Bastos, L. C. Costa, C. Pirmez, A. Iñiguez, A. C. Vicente, C. M. Morel, and L. F. Ferreira. 1998. Paleoparasitology: Perspectives with new techniques. Revista do Instituto de Medicina Tropical de São Paulo 40:371-376. Available at: http://www.scielo.br/scielo.php?script=sci_arttext\&pid=S003646651998000600006\&lng=en\&nrm=iso\&tlng=en.

- - L. F. Ferreira, E. Pucu, and P. P. Chieffi. 2013. Paleoparasitology: The origin of human parasites. Arquivos de Neuro-Psiquiatria 71: 722-726.

Aspock, H. 1996. Parasites and parasitic diseases in prehistoric human populations in Central Europe. Helminthologia 36: 139-145.

, H. Auer, and O. Picher. 1995. The mummy from the Hauslabjoch: A medical parasitology perspective. Alpe Adria Microbiology Journal 2: 105-114.

, H. Flamm, and O. Picher. 1973. Intestinal parasites in human excrements from prehistoric salt-mines of the Hallstat Period (800350 B.C). Zentralblatt für Bakteriologie, Parasitenkunde, Infektionskrankheiten und Hygiene. Erste Abteilung Originale 233: 549-558.

Aufderheide, A. C., W. Salo, M. Madden, J. Streitz, J. Buikstra, F. Guhl, And M. Allison. 2004. A 9,000-year record of Chagas' disease. In Proceedings of the National Academy of Sciences of the U.S.A. 101: 2034-2039.

Bouchet, F. 1995. Recovery of helminth eggs from archeological excavations of the Grand Louvre (Paris, France). Journal of Parasitology 81: 85-87.

. 1997. Intestinal capillariasis in neolithic inhabitants of Chalain (Jura, France). Lancet 349: 256.

, AND S. Bentrad. 1997. Recovery of equine helminth eggs in a mediaeval lacustrine settlement (Charavines, Isère, France). Veterinary Record 141: 601-602.

, S. Harter, J. C. Paicheler, A. Aráujo, and L. F. Ferreira. 2002. The first recovery of Schistosoma mansoni eggs from a latrine in Europe (15th-16th). Journal of Parasitology 88: 404-405.

- C. Lefevre, D. West, and D. Corbett. 1999. First paleoparasitological analysis of a midden in the Aleutian Islands (Alaska): Results and limits. Journal of Parasitology 85: 369-372.

Callen, E. O., and T. W. M. Cameron. 1960. A prehistoric diet revealed in coprolites. New Scientist 8: 35-40. 
Cleeland, L. M., M. V. Reichard, R. Y. Tito, K. J. Reinhard, and C. M. LEWIS JR. 2013. Clarifying prehistoric parasitism from a complementary morphological and molecular approach. Journal of Archaeological Science 40: 3060-3066.

Cockburn, A., R. A. Barraco, T. A. Reyman, and W. Peck. 1975. Autopsy of an Egyptian mummy. Science 187: 1155-1160.

DARLing, S. T. 1920. Observations on the geographical and ethnological distribution of hookworms. Parasitology 12: 217-233.

DitTmar, K. 2009. Old parasites for a new world: The future of paleoparasitological research. A review. Journal of Parasitology 95: 365-371.

—, A. Araújo, and K. J. Reinhard. 2012. The study of parasites through time: Archaeoparasitology and paleoparasitology. In A companion to paleopathology, A. L. Grauer (ed.). Wiley Blackwell, Oxford, U.K., p. 170-190.

Dutour, O. 2013. Paleoparasitology and paleopathology. Synergies for reconstructing the past of human infectious diseases and their pathocenosis. International Journal for Paleopathology 3: 145-149.

Faulkner, C. T. 1991. Prehistoric diet and parasitic infection in Tennessee: Evidence from the analysis of desiccated human paleofeces. American Antiquity 56: 687-700.

$\longrightarrow$, AND S. PAtTon. 2001. Pre-Columbian hookworm evidence from Tennessee: A response to Fuller (1997). Medical Anthropology 20: 92-96.

, AND S. S. Johnson. 1989. Prehistoric parasitism in Tennessee: Evidence from the analysis of desiccated fecal material collected from Big Bone Cave, Van Buren County, Tennessee. Journal of Parasitology 75: 461-463.

Ferreira, L. F., And A. Araújo. 1996. On hookworms in the Americas and trans-Pacific contact. Parasitology Today 12: 454

, AND U. Confalonieri. 1980. The finding of eggs and larvae of parasitic helminths in archaeological material from Unaí, Minas Gerais, Brazil. Transactions of the Royal Society of Tropical Medicine and Hygiene 74: 798-800.

— AND — 1983. The finding of helminth eggs in a Brazilian mummy. Transactions of the Royal Society of Tropical Medicine and Hygiene 77: 65-67.

coprolites dated from 30,000 years ago. Journal of Parasitology 77 . 491-493.

, AND B. RiBEIRO. 1992. Eimeria oocysts in deer coprolites dated from 9,000 years BP. Memórias do Instituto Oswaldo Cruz 87(Suppl. 1): 105-106.

Fries, C. R., D. K. Beidleman, and J. F. Custer. 1990. Analysis of parasites from 19th Century privy contexts, Wilmington, Delaware. North American Archaeologist 11: 17-27.

FrY, G. F., AND J. G. MoORE. 1969. Enterobius vermicularis: 10,000-yearold human infection. Science 166: 1620

Fugassa, M. H., G. M. Denegri, N. H. Sardella, A. Araújo, R. A. Guichón, P. A. Martinez, M. T. Civalero, and C. Aschero. 2006 Paleoparasitological records in a canid coprolite from Patagônia, Argentina. Journal of Parasitology 92: 1110-1113.

, K. J. Reinhard, K. L. Johnson, S. L. Gardner, M. Vieira, and A. AraúJo. 2011. Parasitism of prehistoric humans and companion animals from Antelope Cave, Mojave County, Northwest Arizona. Journal of Parasitology 97: 862-867.

, N. H. Sardella, V. Taglioretti, K. J. Reinhard, and A. Araújo. 2008. Eimeriid oocysts from archaeological samples in Patagonia, Argentina. Journal of Parasitology 94: 1418-1420.

Fuller, K. 1997. Hookworm: Not a pre-Columbian pathogen. Medical Anthropology 17: 297-308.

Gonçalves, M. L. C., A. Araújo, R. Duarte, J. P. da Silva, K. Reinhard, F. Bouchet, and L. F. Ferreira, 2002. Detection of Giardia duodenalis antigen in coprolites using a commercially available enzyme-linked immunosorbent assay. Transactions of the Royal Society of Tropical Medicine and Hygiene 96: 640-643.

Han, E. T., S. M Guk, J. L. Kim, H. J. Jeong, S. N. Kim, and J. Y. ChaI. 2003. Detection of parasite eggs from archaeological excavations in the Republic of Korea. Memórias do Instituto Oswaldo Cruz 98: 123-126.

Hawdon, J. M., and S. A. Johnston. 1996. Hookworms in the Americas: An alternative to trans-Pacific contact. Parasitology Today 12: 72-74.
Horne, P. D. 1985. A review of the evidence of human endoparasitism in the pre-Columbian New World through the study of coprolites. Journal of Archaeological Science 12: 299-310.

- AND S. Q. KaWASAKi. 1984. The Prince of El Plomo: A paleopathological study. Bulletin of the New York Academy of Medicine 60: 925-931.

- AND J. A. TuCK. 1996. Archaeoparasitology at a 17th Century colonial site in Newfoundland. Journal of Parasitology 82: 512-515.

Hu, S. Y. 1984. Study on the parasite eggs in an ancient corpse from Zhangguo Chu Tomb No. 1 in Mashan brick-field of Jiangling County, Hubei. Chinese Journal of Parasitology and Parasitic Disease 2: 8 .

Iñiguez, A. M., K. J. Reinhard, A. Araújo, L. F. Ferreira, and A. C. P. VICENTE. 2003. Enterobius vermicularis: Ancient DNA from North and South American human coprolites. Memórias do Instituto Oswaldo Cruz 98: 67-69.

Jiménez, F. A., S. Lی Gardner, A. Araújo, M. Fugassa, R. H. Brooks, E. RACZ, AND K. J. ReInHARD. 2012. Zoonotic and human parasites of inhabitants of Cueva de Los Muertos Chiquitos, Rio Zape Valley, Durango, Mexico. Journal of Parasitology 98: 304-309.

Jones, A. K. G., And C. Nicholson. 1988. Recent finds of Trichuris and Ascaris ova from Britain. Paleopathology News 62: 5-6.

Jouy-Avantin, F., C. Combes, J. C. Miskovsky, and H. Moné. 1999. Helminth eggs in animal coprolites from a Middle Pleistocene site in Europe. Journal of Parasitology 85: 376-379.

KLIKS, M. M. 1982. Parasites from archaeological material from Brazil. Transactions of the Royal Society of Tropical Medicine and Hygiene 76: 701 .

1983. Paleoparasitology: On the origins and impact of humanhelminth relationships. In Human ecology and infectious diseases, $\mathrm{N}$. A. Croll and J. H. Cross (eds.). Academic Press, New York, New York, p. 291-313.

. 1990. Helminths as heirlooms and souvenirs: A review of New World paleoparasitology. Parasitology Today 6: 93-100.

Leles, D., S. L. Gardner, K. Reinhard, A. Iñiguez, and A. Araúuo. 2012. Are Ascaris lumbricoides and Ascaris suum a single species? Parasites and Vectors 5: 42. Available at http://www.biomedcentral. com/content/pdf/1756-3305-5-42.pdf.

Loreille, O., AND F. Bochet. 2003. Evolution of ascariasis in humans and pigs: A multi-disciplinary approach. Memórias do Instituto Oswaldo Cruz 98(Suppl. 1): 39-46.

, E. Roumat, O. Verneau, F. Bouchet, and C. Hänni. 2001. Ancient DNA from Ascaris: Extraction amplification and sequences from eggs collected in coprolites. International Journal for Parasitology 31: 1101-1106.

Madsen, D. B. 1989. A grasshopper in every pot. Natural History 89(July): 22-25

Manter, H. W. 1967. Some aspects of the geographical distribution of parasites. Journal of Parasitology 53: 1-9.

Matsui, A., M. Kanehara, and M. Kanehara. 2003. Paleoparasitology in Japan: Discovery of toilet features. Memórias do Instituto Oswaldo Cruz 98: 127-136.

Mitchell, P. D., E. Anastasiou, and D. Syon. 2011. Human intestinal parasites in Crusader Acre: Evidence for migration with disease in the Medieval period. International Journal of Paleopathology 1: 132 137.

Moore, J. G., G. F. Fry, and E. Englert JR. 1969. Thorny-headed worm infection in North American prehistoric man. Science 163: 1324 1325.

, A. W. Grundmann, H. J. Hall, and G. F. Fry. 1974. Human fluke infection in Glen Canyon at AD 1250. American Journal of Physical Anthropology 41: 115-117.

Myšková, E., O. Ditrich, B. SaK, M. Kváč, and T. Cymbalak. 2014 Detection of ancient DNA of Encephalitozoon intestinalis (Microsporidia) in archaeological material. Journal of Parasitology. (In press).

Nansen, P., and R. J. Jorgensen. 1977. Fund af parasitæg i arkæologisk materiale fra det vikingetidige Ribe. Nordisk Veterinaermedicin 29: 263-266.

Oh, C. S., M. Seo, J. Y. Chai, S. J. Lee, M. J. Kim, J. B. Park, and D. H. SHIN. 2010. Amplification and sequencing of Trichuris trichiura ancient DNA extracted from archaeological sediments. Journal of Archaeological Science 37: 1269-1273. 
Ortega, Y. R., and D. Bonavia. 2003. Cryptosporidium, Giardia, and Cyclospora in ancient Peruvians. Journal of Parasitology 89: 635-636.

Peng, W., and C. D. Criscione. 2012. Ascariasis in people and pigs: New inferences from DNA analysis of worm populations. Infection, Genetics, and Evolution 12: 227-235.

PIGG, S. L. 2001. Various perspectives on the origins of pathogens: Questions of evidence. Medical Anthropology 20: 91-92.

PIKE, A. W. 1967. The recovery of parasite eggs from ancient cesspit and latrine deposits: An approach to the study of early parasite infections. In Diseases in antiquity. A survey of the diseases, injuries and surgery of early populations, D. Brothwell and A. T. Sandison (eds.). Thomas Springfield, London, U.K., p. 184-188.

- AND M. Biddle. 1966. Parasite eggs in medieval Winchester. Parasite 40: 293-296.

Pizzi, T., AND H. Schenone. 1954. Hallazgo de huevos de Trichuris trichiura en contenido intestinal de un cuerpo arqueológico incaico. Boletín Chileno de Parasitología 9: 73-75.

Reinhard, K. J. 1990. Archaeoparasitology in North America. American Journal of Physical Anthropology 82: 145-163.

- A. Araújo, L. F. Ferreira, and C. E. Coimbra. 2001. American hookworm antiquity. Medical Anthropology 20: 96-104

—, U. E. Confalonieri, B. Herrmann, L. F. Ferreira, and A. J. G. DE ARAÚJo. 1986. Recovery of parasite remains from coprolites and latrines: Aspects of paleoparasitological technique. Homo 37: 217 239

, L. F. Ferreira, F. Bouchet, L. Sianto, J. M. F. Dutra, A Iniguez, D. Leles, M. Le Bailley, M. Fugassa, E. Pucu et Al. 2013. Food, parasites, and epidemiological transitions: A broad perspective. International Journal of Paleopathology 3: 150-157.

- , R. H. HeVly, AND G. A. ANDERSON. 1987. Helminth remains from prehistoric Indian coprolites on the Colorado Plateau. Journal of Parasitology 73: 630-639.

—, S. A. Mrozowski, and K. A. Orloski. 1986. Privies, pollen, parasites, and seeds, a biological nexus in historic archaeology. Masca Journal 4: 31-36.

—, L. Sianto, J. G. Costello, and K. Swope. 2008. Chinese liver flukes in latrine sediments from Wong Nim's property, San Bernardino, California: Archaeoparasitology of the Caltrans District Headquarters. Journal of Parasitology 94: 300-303.

Richardson, D. J., S. Guillén, R. Beckett, W. Kyle, G. Conlogue, and K. Harper-Beckett. 2012. Archaeohelminthology of the Chiribaya Shepherd, Canis familiaris (700-1476 AD) from southern Peru. Comparative Parasitology 79: 133-137.

Rothhammer, F., M. J. Allison, L. Núñez, V. Standen, and B. Arriaza. 1985. Chagas' disease in pre-Columbian South America. American Journal of Physical Anthropology 68: 495-498.

Ruffer, M. A. 1910. Note on the presence of "Bilharzia haematobia" in Egyptian mummies of the Twentieth Dynasty [1250-1000 BC]. British Medical Journal 1: 16.
SADLER, J. P. 1990. Records of ectoparasites on humans and sheep from Viking-age deposits in the former western settlement of Greenland. Journal of Medical Entomology 27: 628-631.

SAMford, P. M. 1991. Pollen, parasites and privies: Analysis of an early 18th Century privy in Williamsburg. Quarterly Bulletin of the Archaeological Society of Virginia 46: 176-182.

Samuels, R. 1957. Studies of Tritrichomonas batrachorum I. The trophic organism. Journal of Eukaryotic Microbiology 4: 110-118.

- 1965. Parasitological study of long-dried fecal samples. Memoirs of the Society for American Archaeology 19: 175-179.

Schantz, P. M., A. C. Moore, J. L. Muñoz, B. J. Hartman, J. A. Schaefer, A. M. Aron, D. Persaud, E. Sarti, M. Wilson, and A FLISSER. 1992. Neurocysticercosis in an orthodox Jewish community in New York City. New England Journal of Medicine 327: 692-695.

Schmidt, G. D., D. W. Duszynski, ANd P. S. Martin. 1992. Parasites of the extinct Shasta ground sloth, Nothrotheriops shastensis, in Rampart Cave, Arizona. Journal of Parasitology 78: 811-816.

SOPER, F. L. 1927. The report of a nearly pure Ancylostoma duodenale infestation in native South American Indians and a discussion of its ethnological significance. American Journal of Epidemiology 7: 174 184.

Steward, J. H. 1933. Ethnography of the Owens Valley Paiute. University of California Publications in American Archaeology and Ethnology 33: $233-350$.

- 1938. Basin-Plateau aboriginal sociopolitical groups (vol. 120). Smithsonian Institution, Bureau of American Ethnology. U.S. Government Printing Office, Washington, D.C., U.S.A., 346 p.

SzIDAT, L. 1944. Über die Erhaltungsfähigkeit von Helmintheneiern in vor-und frühgeschichtlichen Moorleichen. Zeitschrift für Parasitenkunde 13: 265-274.

TAYLOR, E. L. 1955. Parasitic helminths in Mediaeval remains. Veterinary Record 67: 216-218.

Wei, D. X., W. Y. Yang, S. Q. Huang, Y. F. Lu, T. C. Su, J. H. Ma, W. X. Hu, ANd N. F. XIE. 1981. Parasitological investigation on the ancient corpse of the Western Han Dynasty unearthed from tomb no. 168 on Phoenix Hill in Jiangling County. Acta Academiae Medicinae Wuhan 1: 16-23.

Wood, J. R., J. M. Wilmshurst, N. J. Rawlence, K. I. Bonner, T. H. Worthy, J. M. Kinsella, and A. CoOper. 2013. A megafauna's microfauna: Gastrointestinal parasites of New Zealand's extinct moa (Aves: Dirorithiformes). PLOS One 8: e57315. Available at: http:// www.plosone.org/10.1371/journal.pone.0057315.

WittenberG, G. 1961. Parasites of man in archeological findings. Israel Exploration Society Bulletin 25: 86.

Yang ,W. Y., D. X. Wei, G. F. Song, Z. B. Wu, and R. S. Teng. 1984. Parasitologic investigations on the ancient corpse of Chu Dynasty the warring states unearthed from the Ma-zhuan tomb no. 1, Jiangling County. Acta Academiae Medicinae Wuhan 14: 43-45. 